\title{
Molecular mechanisms of traumatic brain injury in children
}

\author{
A review \\ Pavan Jagannathan, ${ }^{1}$ and Jay Jagannathan, M.D. ${ }^{2}$ \\ ${ }^{1}$ Landon School, Bethesda, Maryland; and ${ }^{2}$ Department of Neurosurgery, University of Virginia \\ Health System, Charlottesville, Virginia
}

Due to plagiarism, this article has been retracted from Neurosurgical Focus.

John A Jane, Sr., M.D., Ph.D.

Editor

We direct you to the following:

Park E, Bell JD, Baker AJ: Traumatic brain injury: Can the consequences be stopped? CMAJ 178(9):1163, 2008

[published online April 22, 2008]. doi:10.1503/cmaj.080282.

http://www.cmaj.ca/cgi/content/full/cmaj;178/9/1163 